\title{
Commentary
}

\section{Flipping the Epigenetic Switch}

\author{
Frederick E. Domann* and Bernard W. Futscher ${ }^{\dagger}$ \\ From the Free Radical and Radiation Biology Program," \\ Department of Radiation Oncology, Carver College of Medicine \\ and Holden Cancer Center, The University of Iowa, Iowa City, \\ Iowa; and the Department of Pharmacology and Toxicology, ${ }^{\dagger}$ \\ College of Pharmacy, Arizona Cancer Center, The University of \\ Arizona, Tucson, Arizona
}

Just as genetic instability is a hallmark of malignant cells, so too is epigenetic instability. ${ }^{1,2}$ A key difference is that, in contrast to permanent genetic alterations, epigenetic changes need not be permanent in either tumor cells or normal cells. Thus, when a cell adopts a new gene expression pattern as a result of epigenetic changes, that cell and its progeny reserve the capability to switch back to previous gene expression patterns. This phenotypic plasticity would provide epigenetic metastable or unstable cancer cells the ability to alter gene expression and appropriately adapt to its environment, as it takes its destructive journey from primary lesion to metastatic colony. For example, it is reasonable to propose that cancer cells would likely directly modulate the expression of genes involved in cell adhesion and motility or the transcription factors that control their expression during cancer progression. Early in cancer development these genes remain active in the primary tumor, however, as natural selection occurs, these genes need be silenced so that the tumor has the necessary phenotypic characteristics to metastasize. Following cancer cell colonization at a distant site, the malignant tumor may require reacquisition of those gene products that suppress the properties of motility and invasion, for example. Regulation of the expression of this complement of genes, through DNA methylation and related epigenetic mechanisms, provides a unique switch mechanism in tumor cells that is not as drastic as mutation. Interestingly, some tumor suppressor genes, such as p53, are typically mutated and deleted, and rarely, if ever, are silenced in association with DNA methylation. ${ }^{3}$ In contrast, some genes with tumor suppressor function, rarely, if ever, are mutated, and often are silenced by aberrant DNA methylation. Examples of this latter class of genes include MGMT, maspin, GST pi, and as is further reported here, ER $\beta$ in prostate cancer. ${ }^{4-10}$

\section{Cancer Evolution}

Cancer progression is characterized by the acquisition of genetic and epigenetic changes that lead to generation of phenotypic diversity among the progeny of cancer cells. The evolution of this diversity allows for the continual selection of cells that possess the most suitable attributes for survival under any given set of conditions in the host.

As the cancer cells undergo their dispersion, it is likely that critical, but potentially transient, changes in gene expression patterns occur as cancer cells break away from a primary tumor and invade local tissues and metastasize to distant sites. One gene that may promote survival in one physiological context (eg, primary tumor site, metastatic colony site) may be deleterious in another physiological context (invasive disseminating tumor). For this reason, altering gene expression patterns epigenetically could account for loss of gene expression under one set of circumstances yet allow for the re-expression of this gene should its function provide a selective advantage later in cancer progression. The contribution by Zhu and colleagues ${ }^{11}$ in this issue of The American Journal of Pathology provides a provocative example of how an epigenetic switch at the ER $\beta$ locus may work in the case of prostate cancer progression.

\section{DNA Methylation, Its Known Accomplices, Epigenetic Instability, and Cancer}

Ordered patterns of DNA methylation exist in the human genome that are common to all normal cell types, such as methylation of satellite sequences and an absence of methylation in all, or almost all, CpG islands. In addition, there are regions of the genome that display cell-typespecific patterns of DNA methylation and these cell-typespecific patterns can be seen from the level of the whole chromosome down to the level of the individual gene. Importantly, these DNA methylation differences are asso-

\footnotetext{
Supported by National Institutes of Health grants to F.E.D. and B.W.F.

Accepted for publication March 22, 2004.

Address reprint requests to Frederick E. Domann, Ph.D., Free Radical and Radiation Biology Program, Department of Radiation Oncology, Carver College of Medicine and Holden Cancer Center, The University of lowa, lowa City, IA 52242. E-mail: frederick-domann@uiowa.edu.
} 
ciated with differences in expression of the affected genes $^{9,12-23}$

Epigenetic regulation is a multifaceted control system, in which CpG methylation is just one of many aspects. Methylcytosine can recruit proteins to the genomic region in which it is localized, and these proteins can act as transcriptional repressors and proceed to alter the DNA topology of the region to render it transcriptionally inert; it is not readily accessible for binding by transcriptional activating factors or RNA polymerase and is not easily transcribed. One of the more completely delineated aspects of this epigenetic regulation has demonstrated that heavily methylated DNA recruits methylcytosine binding proteins to the region, which in turn recruits histone deacetylase complexes that enzymatically deacetylate histones $\mathrm{H} 3$ and $\mathrm{H} 4$; a change in the histone modification state that has been demonstrated to be incompatible with gene transcription, whereas acetylation of multiple lysine residues on histones $\mathrm{H} 3$ and $\mathrm{H} 4$ is associated with a transcriptionally competent or active state. ${ }^{24-27}$ Clearly, other histone modifications are important as well in controlling the epigenetic state (eg, histone methylation), and the interplay of these histone modifications with each other and with DNA methylation is an area of intense research activity. ${ }^{28-30}$ The control of these epigenetic changes and there temporal relationship remain an enigmatic and controversial area.

Disruption of the ordered patterns of DNA methylation is a hallmark of the cancer phenotype. These changes can occur early during cancer evolution and are complex in nature. Overall there is genomic hypomethylation, probably due to a generalized demethylation of satellite sequences. $^{31-34}$ In the face of overall genomic methylation, CpG island promoters often become aberrantly methylated, which is clearly associated with the transcriptional silencing of the associated gene. Targets for aberrant methylation in cancer include cell cycle regulatory genes, genes involved in maintenance of genomic integrity, and metastasis suppressor genes that encode cell adhesion molecules and motility factors. With respect to gene regulatory sequences, it is well documented that hypermethylation of $\mathrm{CpG}$ island regulatory sequences results in the silencing of tumor suppressor genes. ${ }^{5,7,8,35-41}$ Interestingly, the patterns of aberrant methylation of $\mathrm{CpG}$ islands have been shown to be tumor-type specific. ${ }^{42}$

Unlike the genetic mutations that accumulate in a cancer cell, epigenetic mutations (or modifications) can be readily reversed. Thus, when a cell adopts a new gene expression pattern as a result of an epigenetic change, that cell and its progeny retain the capability to revert back to a previous gene expression pattern. Therefore, neoplastic progression should perhaps not be considered as a continual march toward an increasingly aggressive phenotype, but rather as a stochastic trial and error saunter toward an increasingly aggressiveness in a "two steps forward, one step backward" manner. Importantly, CpG methylation and associated epigenetic modifications appear to be causally involved in gene silencing since pharmacological inhibitors of DNA methylation and histone modification can reactivate expression. ${ }^{6,43-45}$ The ability to reverse these cancer-related changes in epige- netic control provides a therapeutic opportunity to target the epigenetic machinery and induce transcriptional reprogramming.

\section{Role of ER $\beta$ in Prostate Cancer}

Despite the fact that estrogens have been used historically to treat prostate cancer, their specific mechanisms of action on the prostate remain largely unknown. Since the discovery of estrogen receptor $\beta(E R \beta)$ in 1996, the role of ER $\beta$ in prostate cancer development and progression has been intensively studied. ${ }^{46,47}$ What is clear is that estrogens, either alone or in combination with androgens, can have potent effects on growth and carcinogenesis of the prostate. Clues to the function of ER $\beta$ in prostate carcinogenesis began to emerge when it was discovered that whereas both $\mathrm{ER} \alpha$ and $\operatorname{ER} \beta$ mRNA and protein were expressed in normal human prostate epithelial cells, ER $\beta$ expression was lost in primary cultures of human prostate carcinoma cells and prostate cancer tissues. ${ }^{48,49}$ On this basis it was suggested that ER $\beta$ may be a negative effector of prostate growth and that its loss could facilitate tumor development. This idea has been complicated, however, by the finding that metastatic lesions of primary prostate cancers often display high levels of ER $\beta$ expression. Taken together, the results appear to indicate that loss of $E R \beta$ is an important early event in prostate carcinogenesis, whereas its re-expression at a later stage of disease progression (in metastatic disease) no longer impairs prostate carcinoma growth and in fact may provide some survival advantage. In addition, the re-expression of $E R \beta$ in metastatic disease also provides an attractive target for therapy in advanced disease.

Interestingly, treatment of both prostate and breast carcinoma cells with the DNA methyltransferase inhibitor 5-aza-2' deoxycytidine (5-aza-dC) led to reactivation of silenced $\mathrm{ER} \alpha$ and in some cases $\mathrm{ER} \beta$, providing evidence that the $\mathrm{ER} \beta$ gene, similar to the $\mathrm{ER} \alpha$ gene, may be subject to regulation by DNA methylation. The new study from Ho's laboratory ${ }^{11}$ published in this issue of The American Journal of Pathology shows that ER $\beta$ is a target for methylation-mediated silencing in human prostate cancer. More interestingly, their results show that the cytosine methylation patterns of the $\mathrm{CpG}$ island change during cancer evolution. In normal tissue the 5' CpG islands associated with exon $\mathrm{ON}$ is unmethylated and the gene is expressed. As the normal tissue evolves to grade $4 / 5$ primary prostate cancer, aberrant methylation of the $\mathrm{ER} \beta$ 5' CpG islands appears coincident with partial or complete loss of ER $\beta$ expression. Later in prostate cancer evolution, Zhu et al $^{11}$ find re-expression of $E R \beta$ in metastatic lesions and this re-expression is associated with the epigenetic switch from a methylated CpG island to an unmethylated $\mathrm{CpG}$ island.

\section{An Elegant Approach}

Zhu and colleagues ${ }^{11}$ used immunohistochemistry to identify $\mathrm{ER} \beta$ expression status in normal human pros- 
tates, prostatic intraepithelial neoplasms (PIN), primary malignant cancers, and metastatic lesions. They then used laser capture microdissection to isolate pure populations of ER $\beta$-positive or -negative epithelial cells from the various samples. From these samples they extracted DNA and performed bisulfite genomic sequencing anal$y$ sis of the ER $\beta$ promoter region. This method is considered by most investigators to be the most rigorous and comprehensive approach to quantitatively assess genomic methylation. Their results clearly indicate that ER $\beta$-positive normal prostate epithelia and PIN lesions maintain the $E R \beta$ promoter in an unmethylated state. In contrast, malignant primary cancers that are ER $\beta$ negative have adopted a distinct pattern of aberrant hypermethylation on the ER $\beta$ promoter. Most interestingly, in both lymph node and bone metastases that were ER $\beta$ positive, the ER $\beta$ promoter methylation pattern had switched back to its unmethylated state. Using ER $\beta$ negative human prostate carcinoma cell lines in vitro the authors showed that 5-aza-dC caused reactivation of $\mathrm{ER} \beta$ expression and demethylation of the ERb promoter. In fact, the observed loss of methyl cytosine from the ER $\beta$ promoter in LNCaP and DU145 cells treated with 5-aza-dC was remarkable, and dramatically exceeded that seen in other similar experiments.

Combining their large methylation data set with powerful statistical and mathematical tools, the authors discovered regional differences in promoter methylation that appeared to correlate with expression status. Along with another recent study, we are beginning to see more sophisticated analyses of DNA methylation patterns that promise to provide new biological insights into the role of DNA methylation in genome function. ${ }^{50}$ These are exciting developments indeed.

In an effort to determine whether these regional differences identified by cluster analysis were causally important to ER $\beta$ gene silencing they used an innovative approach to target increased de novo methylation to specific sequences in the unmethylated promoter of $E R \beta$ positive PC 3 cells. This is one of the few references to this method that we could identify in the literature..$^{51,52}$ If this approach is widely applicable, it represents a potentially powerful new approach to not only manipulating gene expression, but also to shed light on how aberrant de novo methylation during cancer progression might be targeted to specific sequences. The overriding question about this approach is how does it work? Although a mechanism has been proposed whereby transfection of methylated oligonucleotides into cells can target methylation to the genomic DNA, there is little experimental evidence to support the proposed mechanism.

\section{Conclusion}

The rigorous approaches used by Zhu and colleagues ${ }^{11}$ in their analysis of the dynamic regulation of $\mathrm{ER} \beta$ expression by DNA methylation have clearly identified a primary mechanism of regulation of this gene during prostate carcinogenesis. Similar mechanisms will likely apply in other malignancies such as breast cancer as well. These results have reinforced the concept of epigenetic instability in cancer progression, and the existence of an epigenetic switch that participates in driving the natural history of cancer progression.

\section{References}

1. Jaenisch R, Bird A: Epigenetic regulation of gene expression: how the genome integrates intrinsic and environmental signals. Nat Genet 2003, 33(Suppl):245-254

2. Jones PA, Baylin SB: The fundamental role of epigenetic events in cancer. Nat Rev Genet 2002, 3:415-428

3. Soussi T, Beroud C: Assessing TP53 status in human tumours to evaluate clinical outcome. Nat Rev Cancer 2001, 1:233-240

4. Costello JF, Futscher BW, Tano K, Graunke DM, Pieper RO: Graded methylation in the promoter and body of the O6-methylguanine DNA methyltransferase (MGMT) gene correlates with MGMT expression in human glioma cells. J Biol Chem 1994, 269:17228-17237

5. Millar DS, Ow KK, Paul CL, Russell PJ, Molloy PL, Clark SJ: Detailed methylation analysis of the glutathione S-transferase pi (GSTP1) gene in prostate cancer. Oncogene 1999, 18:1313-1324

6. Maass N, Biallek M, Rosel F, Schem C, Ohike N, Zhang M, Jonat W, Nagasaki K: Hypermethylation and histone deacetylation lead to silencing of the maspin gene in human breast cancer. Biochem Biophys Res Commun 2002, 297:125-128

7. Domann FE, Rice JC, Hendrix MJ, Futscher BW: Epigenetic silencing of maspin gene expression in human breast cancers. Int $\mathrm{J}$ Cancer 2000, 85:805-810

8. Esteller M, Hamilton SR, Burger PC, Baylin SB, Herman JG: Inactivation of the DNA repair gene O6-methylguanine-DNA methyltransferase by promoter hypermethylation is a common event in primary human neoplasia. Cancer Res 1999, 59:793-797

9. Futscher BW, Oshiro MM, Wozniak RJ, Holtan N, Hanigan CL, Duan $\mathrm{H}$, Domann FE: Role for DNA methylation in the control of cell-typespecific maspin expression. Nat Genet 2002, 31:175-179

10. Lee WH, Morton RA, Epstein JI, Brooks JD, Campbell PA, Bova GS, Hsieh WS, Isaacs WB, Nelson WG: Cytidine methylation of regulatory sequences near the pi-class glutathione S-transferase gene accompanies human prostatic carcinogenesis. Proc Natl Acad Sci USA 1994, 91:11733-11737

11. Zhu X, Leav I, Leung Y-k, Wu M, Liu Q, Gao Y, McNeal JE, Ho S-M: Dynamic regulation of estrogen receptor $\beta$ expression by DNA methylation during prostate cancer development and metastasis. Am J Pathol 2004, 164:2003-2012

12. Fitzgerald M, Oshiro M, Holtan N, Krager K, Cullen JJ, Futscher BW, Domann FE: Human pancreatic carcinoma cells activate maspin expression through loss of epigenetic control. Neoplasia 2003, 5:427-436

13. Gartler SM, Riggs AD: Mammalian X-chromosome inactivation. Annu Rev Genet 1983, 17:155-190

14. Li E, Beard C, Jaenisch R: Role for DNA methylation in genomic imprinting. Nature 1993, 366:362-365

15. Lindsay S, Monk M, Holliday R, Huschtscha L, Davies KE, Riggs AD, Flavell RA: Differences in methylation on the active and inactive human X chromosomes. Ann Hum Genet 1985, 49:115-127

16. Mohandas T, Sparkes RS, Shapiro LJ: Reactivation of an inactive human $X$ chromosome: evidence for $X$ inactivation by DNA methylation. Science 1981, 211:393-396

17. Ogasawara S, Maesawa C, Yamamoto M, Akiyama Y, Wada K, Fujisawa K, Higuchi T, Tomisawa Y, Sato N, Endo S, Saito K, Masuda T: Disruption of cell-type-specific methylation at the maspin gene promoter is frequently involved in undifferentiated thyroid cancers. Oncogene 2004, 23:1117-1124

18. Schofield PN, Joyce JA, Lam WK, Grandjean V, Ferguson-Smith A, Reik W, Maher ER: Genomic imprinting and cancer: new paradigms in the genetics of neoplasia. Toxicol Lett 2001, 120:151-160

19. Swain JL, Stewart TA, Leder P: Parental legacy determines methylation and expression of an autosomal transgene: a molecular mechanism for parental imprinting. Cell 1987, 50:719-727

20. Venolia L, Gartler SM, Wassman ER, Yen P, Mohandas T, Shapiro LJ: Transformation with DNA from 5-azacytidine-reactivated X chromosomes. Proc Natl Acad Sci USA 1982, 79:2352-2354 
21. Zhang Y, Shields T, Crenshaw T, Hao Y, Moulton T, Tycko B: Imprinting of human $\mathrm{H} 19$ : allele-specific $\mathrm{CpG}$ methylation, loss of the active allele in Wilms tumor, and potential for somatic allele switching. Am $J$ Hum Genet 1993, 53:113-124

22. Feil R, Walter J, Allen ND, Reik W: Developmental control of allelic methylation in the imprinted mouse Igf2 and H19 genes. Development 1994, 120:2933-2943

23. Akiyama $Y$, Maesawa $C$, Ogasawara S, Terashima M, Masuda T: Cell-type-specific repression of the maspin gene is disrupted frequently by demethylation at the promoter region in gastric intestinal metaplasia and cancer cells. Am J Pathol 2003, 163:1911-1919

24. Wade PA, Gegonne A, Jones PL, Ballestar E, Aubry F, Wolffe AP: Mi-2 complex couples DNA methylation to chromatin remodelling and histone deacetylation. Nat Genet 1999, 23:62-66

25. Meehan RR, Lewis JD, McKay S, Kleiner EL, Bird AP: Identification of a mammalian protein that binds specifically to DNA containing methylated CpGs. Cell 1989, 58:499-507

26. Boyes J, Bird A: DNA methylation inhibits transcription indirectly via a methyl-CpG binding protein. Cell 1991, 64:1123-1134

27. Nan X, Ng HH, Johnson CA, Laherty CD, Turner BM, Eisenman RN Bird A: Transcriptional repression by the methyl-CpG-binding protein MeCP2 involves a histone deacetylase complex. Nature 1998, 393: 386-389

28. Strahl $\mathrm{BD}$, Allis $\mathrm{CD}$ : The language of covalent histone modifications. Nature 2000, 403:41-45

29. Rea S, Eisenhaber F, O'Carroll D, Strahl BD, Sun ZW, Schmid M, Opravil S, Mechtler K, Ponting CP, Allis CD, Jenuwein T: Regulation of chromatin structure by site-specific histone $\mathrm{H} 3$ methyltransferases. Nature 2000, 406:593-599

30. Lehnertz B, Ueda Y, Derijck AA, Braunschweig U, Perez-Burgos L, Kubicek S, Chen T, Li E, Jenuwein T, Peters AH: Suv39h-mediated histone H3 lysine 9 methylation directs DNA methylation to major satellite repeats at pericentric heterochromatin. Curr Biol 2003, 13: 1192-1200

31. Gama-Sosa MA, Slagel VA, Trewyn RW, Oxenhandler R, Kuo KC, Gehrke CW, Ehrlich M: The 5-methylcytosine content of DNA from human tumors. Nucleic Acids Res 1983, 11:6883-6894

32. Ehrlich M: DNA methylation in cancer: too much, but also too little. Oncogene 2002, 21:5400-5413

33. Feinberg AP, Vogelstein B: Hypomethylation distinguishes genes of some human cancers from their normal counterparts. Nature 1983 , 301:89-92

34. Feinberg AP, Vogelstein B: Alterations in DNA methylation in human colon neoplasia. Semin Surg Oncol 1987, 3:149-151

35. Graff JR, Herman JG, Lapidus RG, Chopra H, Xu R, Jarrard DF, Isaacs WB, Pitha PM, Davidson NE, Baylin SB: E-cadherin expression is silenced by DNA hypermethylation in human breast and prostate carcinomas. Cancer Res 1995, 55:5195-5199

36. Watts GS, Pieper RO, Costello JF, Peng YM, Dalton WS, Futscher BW: Methylation of discrete regions of the O6-methylguanine DNA methyltransferase (MGMT) CpG island is associated with heterochromatinization of the MGMT transcription start site and silencing of the gene. Mol Cell Biol 1997, 17:5612-5619

37. Rice JC, Ozcelik H, Maxeiner P, Andrulis I, Futscher BW: Methylation of the BRCA 1 promoter is associated with decreased BRCA1 mRNA levels in clinical breast cancer specimens. Carcinogenesis 2000, 21:1761-1765
38. Oshiro MM, Watts GS, Wozniak RJ, Junk DJ, Munoz-Rodriguez JL, Domann FE, Futscher BW: Mutant p53 and aberrant cytosine methylation cooperate to silence gene expression. Oncogene 2003, 22: 3624-3634

39. Merlo A, Herman JG, Mao L, Lee DJ, Gabrielson E, Burger PC, Baylin SB, Sidransky D: 5' CpG island methylation is associated with transcriptional silencing of the tumour suppressor p16/CDKN2/MTS1 in human cancers. Nat Med 1995, 1:686-692

40. Herman JG, Merlo A, Mao L, Lapidus RG, Issa JP, Davidson NE, Sidransky D, Baylin SB: Inactivation of the CDKN2/p16/MTS1 gene is frequently associated with aberrant DNA methylation in all common human cancers. Cancer Res 1995, 55:4525-4530

41. Baylin SB, Fearon ER, Vogelstein B, de Bustros A, Sharkis SJ, Burke PJ, Staal SP, Nelkin BD: Hypermethylation of the $5^{\prime}$ region of the calcitonin gene is a property of human lymphoid and acute myeloid malignancies. Blood 1987, 70:412-417

42. Costello JF, Fruhwald MC, Smiraglia DJ, Rush LJ, Robertson GP, Gao $X$, Wright FA, Feramisco JD, Peltomaki P, Lang JC, Schuller DE, Yu L, Bloomfield CD, Caligiuri MA, Yates A, Nishikawa R, Su Huang H, Petrelli NJ, Zhang X, O'Dorisio MS, Held WA, Cavenee WK, Plass C: Aberrant CpG-island methylation has non-random and tumour-typespecific patterns. Nat Genet 2000, 24:132-138

43. Jones PA, Taylor SM: Cellular differentiation, cytidine analogs, and DNA methylation. Cell 1980, 20:85-93

44. Taylor SM, Jones PA: Multiple new phenotypes induced in 10T1/2 and 3T3 cells treated with 5-azacytidine. Cell 1979, 17:771-779

45. Cameron EE, Bachman KE, Myohanen S, Herman JG, Baylin SB: Synergy of demethylation and histone deacetylase inhibition in the re-expression of genes silenced in cancer. Nat Genet 1999, 21:103107

46. Kuiper GG, Enmark E, Pelto-Huikko M, Nilsson S, Gustafsson JA: Cloning of a novel receptor expressed in rat prostate and ovary. Proc Natl Acad Sci USA 1996, 93:5925-5930

47. Mosselman S, Polman J, Dijkema R: ER $\beta$ : identification and characterization of a novel human estrogen receptor. FEBS Lett 1996, 392: 49-53

48. Horvath LG, Henshall SM, Lee CS, Head DR, Quinn DI, Makela S, Delprado W, Golovsky D, Brenner PC, O'Neill G, Kooner R, Stricker PD, Grygiel JJ, Gustafsson JA, Sutherland RL: Frequent loss of estrogen receptor- $\beta$ expression in prostate cancer. Cancer Res 2001. 61:5331-5335

49. Leav I, Lau KM, Adams JY, McNeal JE, Taplin ME, Wang J, Singh H, Ho SM: Comparative studies of the estrogen receptors $\beta$ and $\alpha$ and the androgen receptor in normal human prostate glands, dysplasia, and in primary and metastatic carcinoma. Am J Pathol 2001, 159: $79-92$

50. Feltus FA, Lee EK, Costello JF, Plass C, Vertino PM: Predicting aberrant CpG island methylation. Proc Natl Acad Sci USA 2003, 100:12253-12258

51. Yao X, Hu JF, Daniels M, Yien H, Lu H, Sharan H, Zhou X, Zeng Z, Li $T$, Yang $Y$, Hoffman AR: A novel orthotopic tumor model to study growth factors and oncogenes in hepatocarcinogenesis. Clin Cancer Res 2003, 9:2719-2726

52. Yao X, Hu JF, Daniels M, Shiran H, Zhou X, Yan H, Lu H, Zeng Z, Wang Q, Li T, Hoffman AR: A methylated oligonucleotide inhibits IGF2 expression and enhances survival in a model of hepatocellular carcinoma. J Clin Invest 2003, 111:265-273 